\title{
The Role of Islam, Ajami writings, and educational reform in Sulemaana Kantè's N'ko
}

\author{
Coleman Donaldson
}

\begin{abstract}
The written words of African Muslims have recently received renewed attention. This stems from a push to go beyond colonial archives as well as concerns with terrorism and Islamic radicalization. While Ajami-that is, African languages written in Arabic script-has been a part of this trend, Manding-language publications in the N'ko script have been overlooked. And yet, this literary industry is distinctly Islamic. Putting the writings of Sulemaana Kantè into conversation with historical authors and his contemporaries, Donaldson demonstrates that N'ko represents an iteration of Afro-Muslim vernacular thought, thereby illuminating Kantè and a body of N'ko and Ajami publications.
\end{abstract}

Résumé: Les écrits des musulmans africains ont récemment reçu une attention renouvelée. Cela découle d'une volonté de dépasser les archives coloniales ainsi que les préoccupations concernant le terrorisme et la radicalisation islamique. Alors que l'Ajami, c'est-à-dire les langues africaines écrites en caractères arabes, fasse partie de cette tendance, les publications en langue mandingue et plus particulièrement en écriture N'ko ont été négligées. Cependant, cette industrie littéraire est distinctement islamique. Mettant les écrits de Sulemaana Kantè en conversation avec des auteurs historiques et contemporains, Donaldson démontre que l'écriture N'ko représente une itération de la pensée vernaculaire afro-musulmane, illuminant ainsi l'œuvre de Kantè ainsi qu'un ensemble de publications d'écriture N'ko et Ajami.

African Studies Review, Volume 63, Number 3 (September 2020), pp. 462-486

Coleman Donaldson is a linguistic anthropologist and postdoctoral research associate at the University of Hamburg. He received his PhD in Educational Linguistics from the University of Pennsylvania and is the founder and director of An ka taa, an organization which provides resources and media for speakers and learners of Manding. E-mail: coleman.donaldson@uni-hamburg.de

(C) African Studies Association, 2020. This is an Open Access article, distributed under the terms of the Creative Commons Attribution-NonCommercial-ShareAlike licence (http://creativecommons.org/licenses/by-nc-sa/4.0/), which permits non-commercial re-use, distribution, and reproduction in any medium, provided the same Creative Commons licence is included and the original work is properly cited. The written permission of Cambridge University Press must be obtained for commercial re-use. doi:10.1017/asr.2019.59 
Resumo: As palavras escritas dos muçulmanos africanos tornaram-se recentemente alvo de redobrada atenção. Este fenómeno surge em consequência de um esforço por ir além dos arquivos coloniais, bem como da preocupação com o terrorismo e com a radicalização islâmica. Ao passo que as línguas ajami — ou seja, as línguas africanas escritas no alfabeto arábico - têm integrado esta tendência recente, as publicações em línguas mandingas, escritas no alfabeto n'ko, têm sido largamente ignoradas. E no entanto, esta produção literária é marcadamente islâmica. Colocando em diálogo os escritos de Sulemaana Kantè e os de outros autores históricos, Donaldson demonstra que o alfabeto n'ko corresponde a uma reiteração do pensamento vernacular afro-muçulmano, assim permitindo aprofundar a leitura de Kantè e de um conjunto de publicações em n'ko e em ajami.

Keywords: N'ko; Manding; Sulemaana Kantè; Ajami; West Africa; Islam

(Received 26 March 2018 - Revised 09 September 2019 - Accepted 09 September 2019)

Sulemaana Kantè is best known for his 1949 invention of a non-Latin-, nonArabic-based script called N'ko. ${ }^{1}$ A prolific author until his death from diabetes in 1987, he used his unique script to write over one hundred books-spanning across such diverse topics as linguistics, history, traditional medicine, and Islam-which continue to be typeset and published today. Kantè's most enduring legacy, however, is neither his script nor any one of the many books that he authored using it. Instead, it is the thousands of West Africans who dedicate themselves to the study and promotion of his creation as either a panAfrican script or a Manding orthography. Understanding what animates the N'koïsants of today, though, is near impossible without a proper understanding

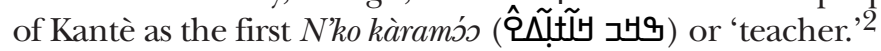

Scholarly accounts thus far (Amselle 2001; Oyler 2005; Wyrod 2003) have underemphasized connections between the inventor of the N'ko alphabet and his historical and contemporaneous Muslim counterparts in what post-colonially became "the Islamic sphere" (Launay \& Soares 1999). Kantè was a particular iteration of what I call "the Afro-Muslim vernacular tradition." He emerged from the regional West African Quranic schooling network and expressed similar sentiments to earlier Ajami intellectuals who had sought to strengthen Islam through literacy in local African languages. Like his predecessors, he faced skepticism-though colored by his particular historical moment following World War II. Put broadly, traditional scholars saw a new writing system and mother-tongue education as a threat to their livelihoods, while rival reformers, the so-called Wahhabis, favored a pan-Islamic identity over the Afro-centric one favored by Kantè that melded pan-Africanism and ethno-nationalism.

In the following three sections, I focus on Kantè, the kàramós, in the full Muslim clerisy sense of the term. First, I introduce his upbringing in the Quranic schooling tradition of West Africa. Second, I lay out parallels between him and his predecessors in an Afro-Muslim tradition which viewed vernacular writing in Arabic script (that is, Ajami) as a tool for both 
strengthening Islam and responding to particular socio-political circumstances. Finally, I explore the specifics of Kantè's N'ko as an iteration of the above traditions influenced by the social forces that were active following World War II and into the earlier years of African independence.

\section{Kantè as a Product of the Afro-Muslim Vernacular Tradition}

Born in 1922, in the Baté ( $\bar{\wedge}$ f báte, literally "between rivers") region of what is now Guinea, Kantè was early on integrated into Islam, which had been present in parts of sub-Saharan West Africa since approximately the ninth century (Austen 2010:85-86; Tamari \& Bondarev 2013:4; Ware III 2014:85). ${ }^{3}$ Like many West African Muslims before him, Kantè was familiar with the Arabic language (Hunwick 1964) — though his knowledge went much further than many - thanks to both the centrality of Quranic verses to prayer and other religious acts. Kantè's interest in the written word was instilled in him and his eleven siblings from an early age. While none of them would follow their father's career path as a móri (Ytح "Quranic school teacher" often used interchangeably with $\hat{\imath} \tilde{\imath}+\tilde{T}+$ tàramśs), they all, at one point or another, attended the school that was their family's livelihood. ${ }^{4}$

The vast majority of the elder Kantè's students would have only attended Quranic school at the first of two levels: the so-called basic level during which a student, for a span of time ranging from a few months to a few years, focuses on learning the "fundamental elements of Islamic religious obligation," such as the proper techniques for ritual ablution, prayer, and the recitation of at least some verses of the Quran (Brenner 2008:220). ${ }^{5}$ Given that Arabic is rarely the mother tongue of West Africans, this early focus on the Quran inevitably entails some rote memorization, but it is far from mindless as suggested in colonial documents (e.g., Mairot 1905 in Turcotte 1983); the elementary cycle itself is divided into numerous discrete stages before students with sufficient mastery of Arabic move onto the second level with its focus on advanced subjects of the Islamic Sciences. ${ }^{6}$

Through this tradition and his father's teaching, Kantè came to master literary Arabic, a language with a historical status akin to the Latin of West Africa (see Hunwick 2004). This written lingua franca had spread not because of Arabic-speaking conquerors, but rather, thanks to the clerical efforts and unique status of Quranic teachers, or "walking Qurans" (Ware III 2014), who were free in many cases to travel and settle across West Africa for centuries prior to colonial rule. ${ }^{7}$ These same scholars' skills in Arabic literacy were also applied to the administrative and communication needs of various West African polities and courts such as that of Mali's Mansa Musa in the fourteenth century. ${ }^{8}$ Linguistic analysis has also long provided evidence of this history of Arabic as a regional language of learning and correspondence (see Green \& Boutz 2016; Zappa 2011). Kantè likely noted this early on in his education; later he (2007/1958) would write: 


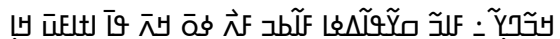

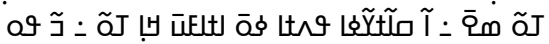
Ũ مة

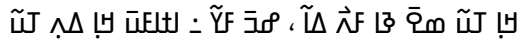
乙̄

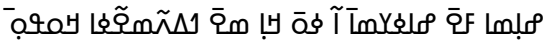
(\% $\overline{\mathrm{Z}} \boldsymbol{\mathrm { Z }} \tilde{\mathrm{O}} \mathrm{J}$

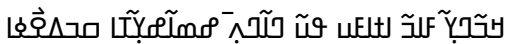

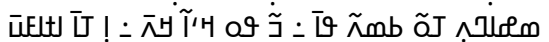

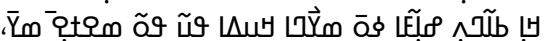

Because all of Islam's worship is done in Arabic, its legal books are in Arabic. This is what has latched African Muslims to Arabic to this day and this is also what proliferated Arabic words in our languages in so many ways. Presently, the amount of Arabic [words] in the Mandings' language is near 300 and some; it is almost $1 \%$ of the language.

Yet because the Arabs came upon African civilizations as complete, the majority of borrowed Arabic is religious vocabulary only. (1)

While his education took place primarily in Arabic, Kantè reports having been introduced formally to the practice of writing a sub-Saharan African language in Arabic script in $1941 .{ }^{9}$ In this way, he was likely connected to an older tradition; residents of the Batè region probably began flirting with writing their own language sometime in the nineteenth century. ${ }^{10}$ At the time however, Kantè was not impressed. Presented with a history-written in Manding by his grandfather and maternal uncle using the Arabic script—of the ethnic Fulani of the pre-colonial polities of Batè and neighboring Wasolon, he found that he could not read the text. His uncle's remark that the document served primarily as memory-jogging device for the author did little to convince Kantè, who recalled thinking:

\begin{tabular}{|c|c|}
\hline 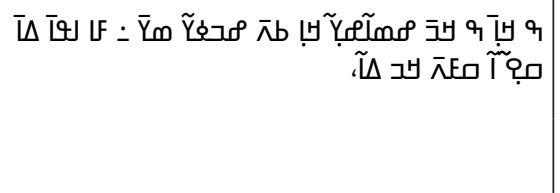 & $\begin{array}{l}\text { I said African languages are worthless } \\
\text { because God has not allowed for them to be } \\
\text { written. } \\
\text { (Kánte 1968:4) }\end{array}$ \\
\hline
\end{tabular}

Blinded, as he would later put it, to facts demonstrating that writing did not in fact stem from God, Kantè thought little more of writing African languages for the next few years (Sangaré 2011).

A number of other West Africans in the centuries before him had not reached the same hasty conclusion. And while they did not arrive at his ultimate solution of inventing a script, these Muslim scholars often had trajectories and ideas similar to those that Kantè would later develop regarding mother-tongue education.

\section{Kantè's Desire to Strengthen Islam as Stemming from the Vernacular Ajami Tradition}

Important initial academic scholarship on N'ko analyzes it as a primarily anti-colonial intellectual movement. ${ }^{11}$ Refining this work, Jean-Loup 
Amselle (2001; 2003) rightfully highlights N'ko's connection with Islam and the wider Muslim world. On his account, however, N'ko is an ethnoreligious fundamentalist movement that utilizes the "invented tradition" (Ranger 2010) of French colonial Islam noir ("Black Islam") to combat the efforts of West African Muslim Wahhabi reformists (Kaba 1974; Brenner 2001) and thereby preserve "a 'Negro-african' specificity within the Muslim community" (Amselle 2003:257). ${ }^{12}$ His overly harsh positioning of N'ko activists as fundamentalists aside, Amselle's analysis does not properly situate Kantè's thoughts and actions within the West African Quranic tradition. Islam figures prominently in Kantè's (2008a:7) characterization of his intellectual oeuvre and must be taken seriously: ${ }^{13}$

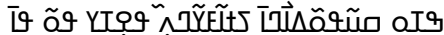 ـ 积

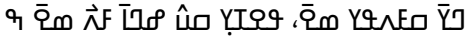 كَ}

I, Sulemaana Kantè, am more passionate about knowledge than anything else on earth. As such, I would like for all my brothers and neighbors to have some knowledge of reading and writing. Of all the kinds of knowledge, I love three the most:

First: Knowledge of Islam's worship rituals and laws. This led me translate the Quran and the Prophet's sayings into N'ko because they are the key of the religion.

Just as the script of Rome was eventually co-opted for penning a number of other languages besides Latin, the Quranic tradition of Arabic literacy also lent itself to the development of a written tradition for a large number of sub-Saharan African languages. ${ }^{14}$ Today, this tradition of writing local vernaculars in the Arabic script is commonly referred to in West Africanist research as Ajami (from the Arabic 'ajam, عجم 'non-Arab, Persian'). ${ }^{15}$ The earliest evidence that we have of such literacy in the region dates back to the seventeenth century, when a scholar residing in the Kanem state north of Lake Chad inserted interlinear glosses of Kanuri inside a copy of the Quran (Bondarev 2013; Tamari \& Bondarev 2013). Existing documents and research thus far suggest that it was during the eighteenth century that robust traditions of Ajami began to emerge for a number of West African languages. In many cases, Ajami was a "grassroots literacy" (Blommaert 2008) that existed in the Quranic schooling system's margins. In other cases, however, Ajami literacy was "undertaken by individual scholars to solve language problems and modify the linguistic behaviours in West African communities" (Diallo 2012:97). Such efforts to modify linguistic and literacy practices-as all instances of language planning-were part and parcel of quests for social change ${ }^{16}$ Analyzing the voices of the Ajami tradition therefore allows us to better understand how Kantè did not simply co-opt French colonial Islam noir but rather innovated within a much longer tradition expressed in, though not exclusive to, vernacular thought. 
In what follows, I briefly sketch the intertwined emergence of Ajami literacy traditions in four major West African languages of the Muslim Sahel. ${ }^{17}$ See Figure 1 for a non-exhaustive map of these language's Ajami traditions and their relevant locales.

\section{Fulani and Hausa}

The eighteenth century gave rise to two regional traditions of Fulani Ajami in Fuuta Jaloo (spelled Fouta-Djallon in French) and Hausaland, in modern-day Guinea and Nigeria respectively (see Hunwick 2004; Zito 2012). In both cases, the emergence of Ajami was tightly connected to Fulani Jihads which aimed to spread Islam and which gave rise to the aforementioned polities.

In Fuuta Jaloo, the first known Ajami practitioner was Cerno Samba Mambeyaa, (1755-1852), who explicitly justifies his decision to write in Fulani as follows:

I shall use the Fulfulde [Fulani] tongue to explain the dogma.

In order to make their understanding easier: when you hear them, accept them!

For only your own tongue will allow you to understand what the Original texts say. Among the Fulani, many people doubt what they read in Arabic and so remain in a state of uncertainty.

(Salvaing 2004:111-12)

To this end, Mambeyaa's works were primarily religious texts written in verse form that may have emulated the oral commentaries traditionally performed to the public by Fulani clerics. His innovation therefore was to believe that regular Fulani should have access to these commentaries in written form. Such a shift, in his mind, would strengthen Islam and spread

\section{Figure 1. Map of select traditions of Manding, Wolof, Fulani, and Hausa Ajami literacy}

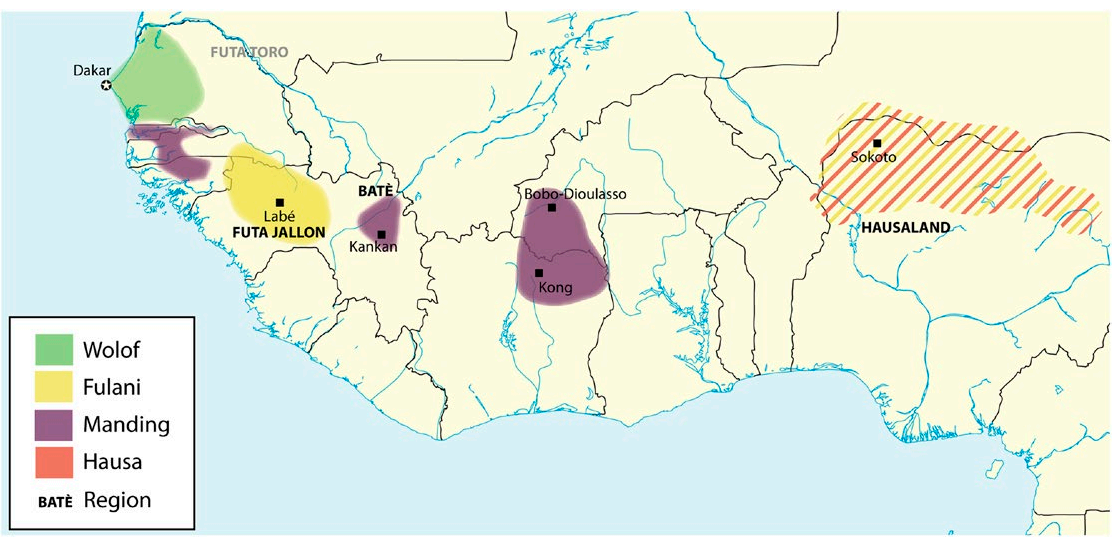


religious fervor among the Fulani people. This goal remained central; at the end of the nineteenth century, all Fuuta Jaloo Ajami writings continued to focus on religious matters (Salvaing 2004:111-12).

Similarly, Fulani Ajami emerged with Shaykh Usman Dan Fodio's (1754-1817) rise to power in establishing the nineteenth-century Sokoto caliphate in what is now largely northern Nigeria. ${ }^{18}$ Dan Fodio's zeal to spread Islam among the general populace led to the flourishing of both Fulani and eventually Hausa Ajami. While Dan Fodio himself wrote primarily in Arabic, he did pen a number of original texts as well as translations of his Arabic works into Fulani, his mother tongue, and Hausa, the dominant language of the conquered masses. Echoing Mambeyaa's concern with propagating Islam, Dan Fodio began one of his poems as follows:

My intention is to compose a poem on the [prostration] of forgetfulness. I intend to compose it in Fulfulde [viz. Fulani] so that Fulbe [viz. Fulani] could be enlightened.

When we compose [a poem] in Arabic only the learned benefit.

When we compose it in Fulfulde the unlettered also gain. (Diallo 2012:1)

Thus, while learned discourse took place in written Arabic, Dan Fodio believed that disseminating Islamic knowledge more broadly could be assisted by composing the kinds of verses that had served to spread Islam orally in years prior. ${ }^{19}$ This trend and encouragement from Dan Fodio would give rise to a robust tradition of Fulani and increasingly Hausa Ajami that was carried out by his disciples and those in his entourage such as his brother as well as his daughter, Nana Asmā'u (see Mack \& Boyd 2000).

As evidenced by the declarations of both Dan Fodio and Mambeyaa, this evolution was not an unquestioned natural progression. Indeed, local tradition suggests that Mambeyaa's efforts were opposed by Umar Tal (1794-1864), the leader of the first major Fulani jihad that took place around the Senegal River's region of Fuuta Tooro (Salvaing 2004). Tal's position along with Fuuta Tooro's proximity to the Moors of West Africa have also been advanced as reasons for the lack of a robust Ajami tradition in this other major Fulani area (see Ngom 2009:101; Robinson 1982) ${ }^{20}$ This tension and its connection to race debates within Islam in West Africa emerge even more strongly in the case of Wolof.

\section{Wolof}

The Ajami tradition of Wolof, commonly referred to as Wolofal, emerged primarily out of the Sufi Muslim brotherhood, the Muridiyya (المريدية al-muridiyya), established by Shaykh Amadu Bamba (1850-1927). Wolofal is still extensively practiced in Senegal today in both formal publications and more mundane record-keeping, signs, and correspondence (Ngom 2010). Fallou Ngom $(2009 ; 2016)$ suggests that the nineteenth century flourishing of 
Wolof Ajami can be traced to the personality and teachings of Amadu Bamba. The Muriddiya's leader asserted a strong African identity as part of his broader Islamic message; he addressed French colonialism and its supposed superiority but he also "differentiated the essence of Islamic teaching from Arab and Moorish cultural practices with no spiritual significance" (Ngom 2009:104). Bamba, for instance, did not claim Sharifan or Arab descent for prestige or to legitimize his message. ${ }^{21}$ While he did not write in Wolofal himself, he supported its development and use by his senior disciples such as Muusaa Ka (Camara 1997) who used it to spread Islam and Bamba's message to the masses. In this sense, Wolof Ajami emerged for the same reason as that of Fulani and Hausa-to more effectively promote Islam and religious teachings. As Muusaa Ka explains in the introduction to one of his poems:

The reason this poem-which should have been sacred-is written in Wolof

Is that I hope to illuminate the unknowing about his Lord. (Camara 1997:170)

According to Fallou Ngom (2009), this aim is also connected to Bamba's own desire for African cultural autonomy. At least once in writing, Bamba explicitly engaged with the issue of race and hierarchy within Islam; in his work Masālik al-Jinān (مسالك الجنان "Itineraries of Heaven”) he writes:

Do not let my condition of a black man mislead you about the virtue of this work, because the best of man before God, without discrimination, is the one who fears him the most, and skin color cannot be the cause of stupidity or ignorance. (cited in Babou 2007:62)

From this position, Bamba (similarly to Kantè in the twentieth century) had no qualms calling upon traditions such as Wolof proverbs as a means to translate his Islamic message to the Wolof masses (Ngom 2009:107). While he himself wrote in Arabic, perhaps because of a spiritual desire to "commune with God and the prophet Muhammed" (Camara 1997:170), Bamba articulated an explicit Afro-Muslim identity that gave "ideological and implementational space" (Hornberger \& Johnson 2007) for local language Ajami literacy to flourish. This overt engagement with issues of race and cultural autonomy within Islam makes the Wolofal tradition seemingly unique, but ethnic relationships-mediated, today at least, in part by notions of race-are alluded to in other accounts of Ajami literature's emergence (see Ngom 2009 for Fulani/Moor and Robinson 1982 for Fulani/Manding).

\section{Manding}

Sulemaana Kantè did not emerge directly from the Wolof, Hausa, or Fulani traditions. He grew up, however, in a place with close ties to the historical 
region Màndén, which gave rise to what historians refer to as the Mali empire. ${ }^{22}$ While it is unclear what role Islam played among this polity's masses, we have evidence that Arabic was used in Mali's court and was even spoken by the empire's sovereign, Mansa Musa, when he performed his pilgrimage to Mecca in the fourteenth century (Hunwick 1964). Nonetheless, a Friday prayer in Arabic was translated spontaneously into Manding in the fourteenth century and therefore it seems likely that the language was a developed medium of oral scholarly discussion and religious propagation by the fifteenth century. ${ }^{23}$ The oldest tradition of Islam among Manding speakers seems to be traceable to the jülá network that originated first with Muslim Soninke traders that spread out across West Africa during the Ghana empire that preceded that of Màndén (see Wilks 1968, 2000) (See Figure 2).

During the Mali empire, which reached its apogee in the fourteenth century, the Muslim Jula network of traders became increasingly Manding; that is, older Soninke members adopted the language of Mali and were additionally joined by other Manding-speaking Muslims along their trading routes and outposts (Massing 2000). Thus, while the decline of the Mali empire led to many non-Muslim polities (e.g., Kaabu and Segu)

Figure 2. Map of Màndén, the Ghana and Mali empires, and Jùlá trade network (Sources: Dalby 1971; Launay 1983; Simonis 2010)

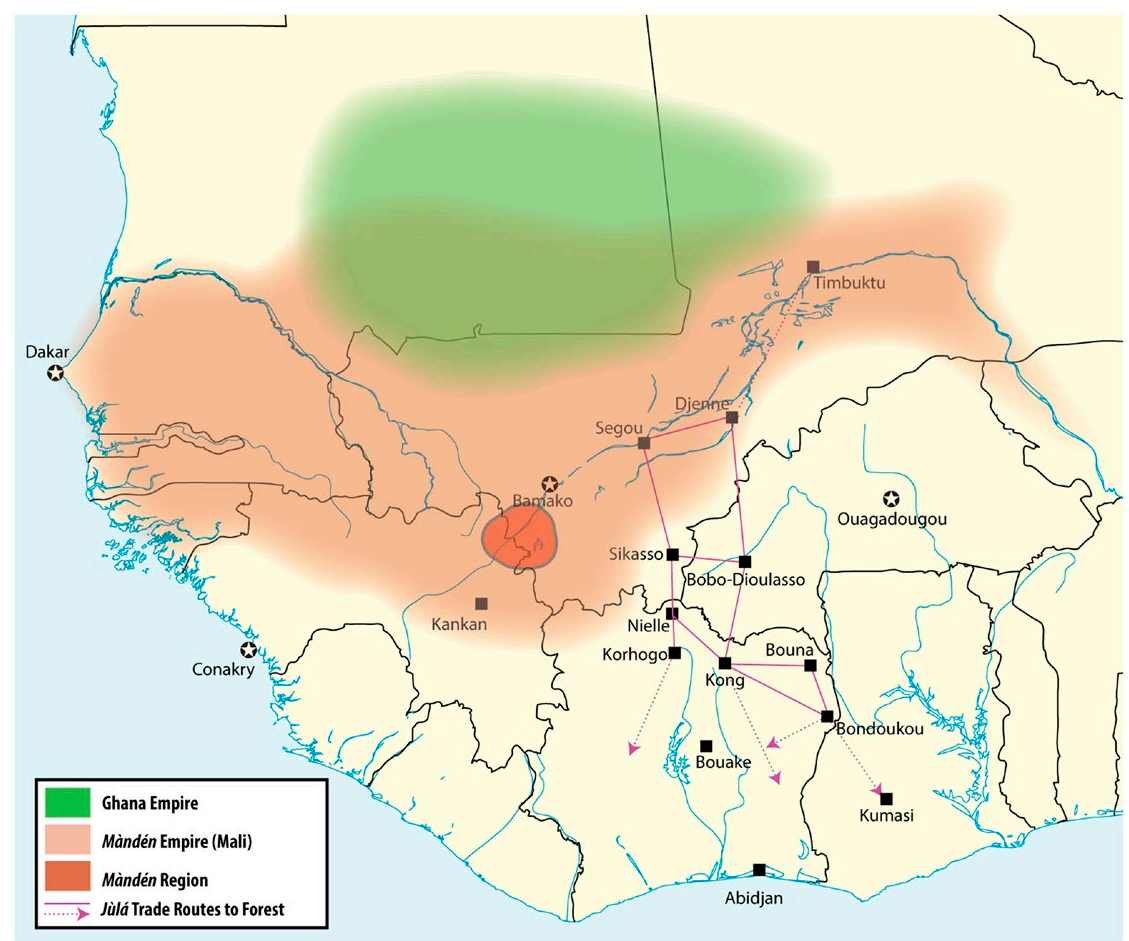


where Ajami would have been less likely to emerge, we nonetheless find evidence of Manding Ajami traditions in a number of areas (Vydrin 1998; Vydrin 2014). 24

Specifically, the Islamic tradition of the Jakhanke Muslim clerics (a western iteration of the Jula network) in southern Senegambia gave rise to Ajami that was attested to as early as the late seventeenth century. ${ }^{25}$ It is also in and around this Mandinka-speaking region that Manding Ajami practices appear the strongest today. The earliest Western documentation of Manding Ajami elsewhere stems primarily from areas in Burkina Faso and Côte d'Ivoire. ${ }^{26}$ Valentin Vydrin (2014) suggests that this was surely an area with an older Manding Ajami tradition. Indeed, this part of the Jula network gave rise to the Kong Empire and its vaunted scholarly tradition. ${ }^{27}$ Any Ajami documents that may have existed in Kong were destroyed when the town and its libraries were sacked and burned by Sămòri Tùre in the late nineteenth century (see Fofana 1998; Person 1968; Peterson 2008).28 While we know of no major Ajami collections in the zone today, Ajami is still practiced in the margins of the Quranic schooling tradition (Donaldson 2013).

Outside of the western Jakhanke- and Mandinka-speaking areas, it is only in the case of Kantè's native region around Kankan that we currently have any specific information on a potential pre-twentieth-century Manding Ajami tradition. Kantè considered himself the heir to the work of Alfa Mahmud Kàbá (I. Condé 2008b:135; N. S. Condé 2017:117). ${ }^{29}$ Popularly understood as a skilled leader who unified the Batè region in the mid-nineteenth century, Kàbá was also a man of letters. He is known for his works in Arabic as well as his (presumably oral) translation of Islamic poems into Manding. ${ }^{30}$ Ibrahima Condé (2008b) suggests he may have been the first to attempt to pen Manding in the Arabic script. In the early twentieth century, a contemporary and friend of Kantè's father, Jakagbe Talibi Kàbá was also concerned with translating Islamic rites and poems into Manding and is purported to also have attempted to create a unique writing system for Manding (Condé 2008b:135). ${ }^{31}$ Despite not having access to any texts, with both of these authors, we see that Manding Ajami arose alongside the Arabic-language tradition, in part, for the purpose of spreading the gospel of Islam. ${ }^{32}$

In sum then, just as West African speakers of Fulani, Hausa, and Wolof pondered the place of their mother tongues in promoting Islam, so did Manding Muslims, despite a relative dearth of identified Ajami textual artifacts in the major Eastern Manding varieties of Bamanan, Jula, and Maninka. Kantè was a direct intellectual heir to Alfa Mahmud Kàbá and Talibi Kàbá of Kankan. However, given the transnational character of Quranic schooling and clerical communities in West Africa, it is important to see that Kantè was also connected indirectly with thinkers among Fulani, Hausa, and Wolof Muslims. In this sense, we have severely underestimated the role of Kantè's Quranic education in his life and work: 
In his reflection on the Manding language and his interest for its different regional varieties, in his quest for a perfectly adequate vocabulary to express theological, philosophical, logic or linguistic concepts, by strongly distinguishing between Islam and Arabness, [Kantè] was pursuing preoccupations and manifesting points of view well anchored amongst clerics [Fr. les lettrés] (Tamari 2006:51-52)

\section{Kantè's Desire to Reform Islamic Education}

N'ko's founder represents a particular iteration of the Afro-Muslim vernacular tradition. While rooted in the ideas laid out above, Kantè also sought to respond as a Muslim educator and intellectual to his own historical moment of post-World War II and the independence era.

The aftermath of World War II "presented opportunities to political and social movements to take on imperial administrations uncertain of their continued authority and aware of their need of Africans' contributions to rebuilding imperial economies" (Cooper 2002:26). The post-war moment also revealed tensions in what Robert Launay and Benjamin F. Soares (1999:498) describe as the newly-formed Islamic sphere, "separate [...] from 'particular' affiliations-ethnicity, kin group membership, 'caste' or slave origins, etc.— but also from the colonial (and later the post-colonial) state." While West African Muslims had undoubtedly always discussed proper membership in the Islamic community, the debate tended to be restricted to internal discussions among the largely hereditary clerical class. The colonial period's major shifts in political economy disrupted such traditional religious authority and carved out space for larger societal debates about Islam and Muslim identity (Launay \& Soares 1999:501). As such, as elsewhere on the Continent (Brenner \& Last 1985; Peterson 2006), the postwar moment in French West Africa gave rise to unique and competing Muslim experimentations with language-in-education that were designed to address both the French colonial system as well as concerns in the Islamic sphere.

Kantè's father, Amara, was likely at the origin of the N'ko inventor's interest in pedagogical reform; the elder Kantè was himself an innovator. His instructional methods facilitated an accelerated program which attracted a large body of Manding-speaking students with origins spread out across West Africa (Sangaré 2011; Oyler 2005).

Sulemaana took responsibility for teaching his father's students following his father's death in 1941 (Sangaré 2011:10-11). By 1942, though, he had decided to seek his fortune away from home and left with the intention to settle either with "people looking for a Quranic teacher" or in "one of the White man's cities” (Sangaré 2011:12-13; see also Amselle 2001:150). (See Figure 3 for a map of Kantè's travels within his broader life.)

Kantè's decision was typical; many young male Sahelian Muslims (oftentimes Manding-speakers) at the time were drawn to the economic opportunities of southern Côte d'Ivoire. For Kantè, it was in the city of Bouaké that the invention of N'ko was set in motion: 


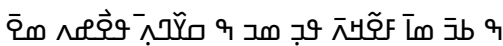
Uا

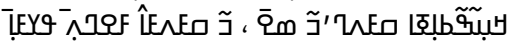

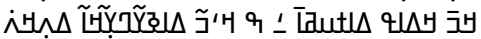
Uٓ นิ

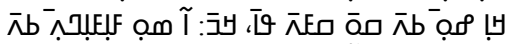

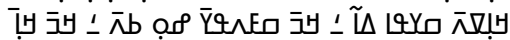

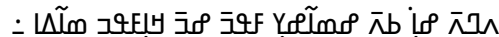

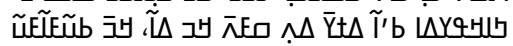

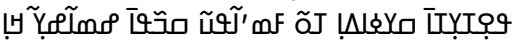

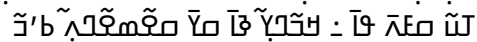

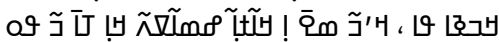
حَّ
One day, sitting at the marketplace in Bouaké, I saw some book for sale with something about African stupidity on it. Its writer was from Lebanon and named Kamal Maruwa [Kamal Marwa]. He was saying that African ignorance never ends. He said, first, none of their languages can be written; they aren't made according to any grammar. They aren't meant for writing; they were made for speaking only. They don't actually have a true language, just dialects that no intelligent person would waste their time thinking about writing. Lots of Europeans have become interested in writing African languages, but there is just no way. He said, teaching us European languages is easier than teaching us our own languages. (Sangaré 2011:16)

It was true, Kantè said, Africans didn't have a writing system, but it was insult to injury to spread the lie that their languages were deprived of grammar. ${ }^{33}$ His rancor drove him to attempt to write Manding (Sangaré 2011:17-18).

Likely equally important and not sufficiently taken into account in previous analyses, however, are the voices of his fellow Manding-speaking Muslims that he encountered during the same period. The town in which he encountered Marwa's book was central to the post-War madrasa movement,

Figure 3. Approximate map of Kantè's post-1941 travels and history of residence in West Africa (as per Amselle 2003; Kánte 2013:200; Oyler 2005; Sangaré 2011)

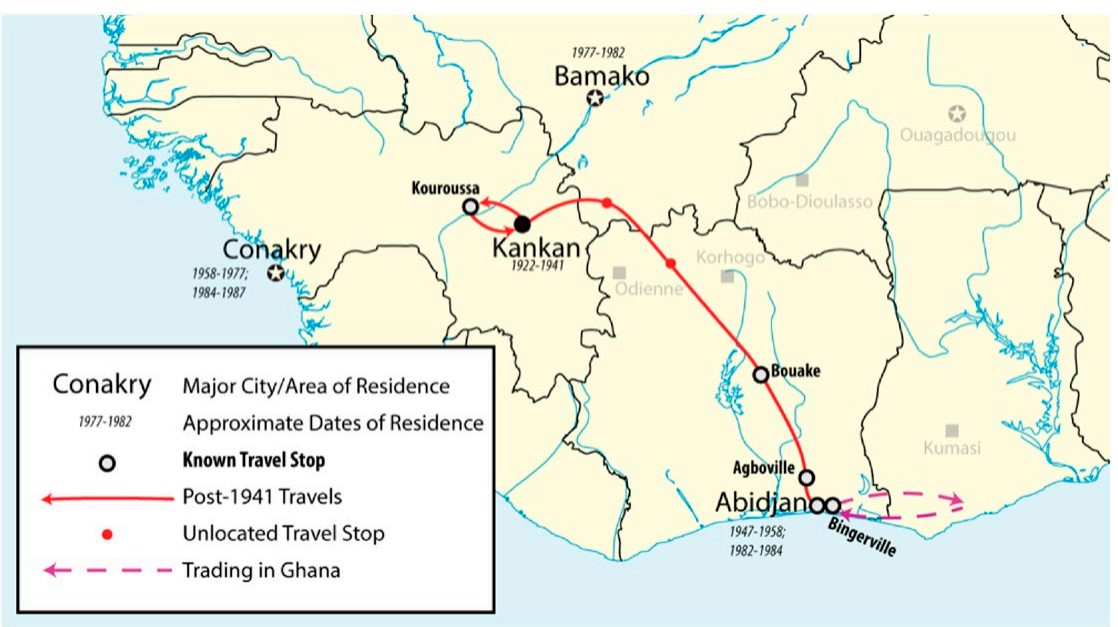


which established a string of modernist Muslim schools that used Arabic as the medium of instruction but followed the curriculum and practices of Western-style francophone schools. ${ }^{34}$ Bouaké opened its first madrasa school as early as 1948 (Leblanc 1999:492). Such schools were the product, on one hand, of so-called Wahhabi doctrinal reformists that connected during or upon return from sojourns in the Middle East (Kaba 1974) and, on the other, of educational reformists simultaneously questioning the traditional Quranic schooling elite and seeking to prepare students in a Muslim manner for integration into the emerging modern economy (Brenner 1991:65). Their Arabic language policy stemmed in part from a prevalent rationalist tenant in modernist Islamic circles "that texts are transparent and that grasping their manifest meaning makes their prescriptions clear" (Ware 2014:70).

While any specific encounters with educational reformists or preachers such as Al-Hajj Tiekodo Kamagaté (to whom Kaba [1974] traces the origin of so-called West African Wahhabi reformism) remain undocumented, Kantè was unquestionably a part of the rising younger generation of so-called jùlá traders in Côte d'Ivoire who were hearing and debating new ideas about Islam and society. For reformists such as Kamagaté, madrasas offered both popular access to Islam through Arabic acquisition in schooling and a means to short-circuit the elite role traditionally played by Quranic teachers as religious intermediaries. Unsurprisingly, those behind this shift to Arabic were also frequently engaged in larger doctrinal critiques of traditional Sufi clerics at the top of the Quranic schooling system (Kaba 1974).

Shortly after encountering Kamal Marwa's tract, Kantè headed south, eventually settling in Bingerville, where he set up shop as a Quranic teacher before entering the Kola nut trade. His free time was dedicated to devising a way to write Manding (Sangaré 2011:19). N'ko students today largely attribute this quest to the blind, if not racist, ignorance of Marwa. However, analyzing Kantè's own writings regarding the reactions of fellow Quranic scholars reveals the extent to which his activities were also an attempt to intervene in the Islamic context of both Quranic schools and the newlyformed madrasas.

For three years, he initially experimented with writing Manding with the Arabic script. His efforts were discouraged by those affiliated with

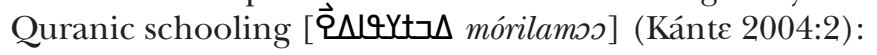

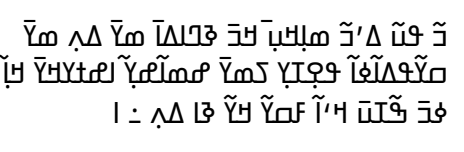

They didn't recognize it as something good that would reinforce Islamic knowledge in Black Africa as we thought it would.

Ultimately, Kantè, however, saw vernacular literacy as having major implications for his religion and its education system. (Kánte 2004:6): 
دَّ

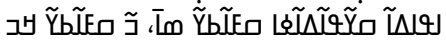

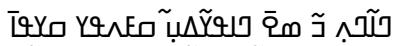
: ר
They [clerics] themselves are always saying "May God strengthen Islam." This strengthening has come in the shortcut of writing. What is their reason for refusing if they are serious about strengthening the religion?

He subsequently spent two years experimenting with the Latin script, before ultimately concluding that to forge this shortcut, he must create a unique writing system with conventions adapted to the tonal and vowel lengthening systems of West African languages such as Manding. ${ }^{35}$

On April 14, 1949, while residing in Bingerville, Côte d'Ivoire, Sulemaana Kantè, after five years of experimentation, unveiled the non-Arabic, nonLatin-based script of twenty-eight characters written right-to-left that he called N'ko. ${ }^{36}$ He would subsequently dedicate the rest of his life to research, writing, and teaching using his so-called African Phonetic Alphabet. Similarly to the madrasa movement, Kantè's effort was part of a rationalist project, as revealed in his many writings as "an Enlightenmentstyle encyclopediast” (Vydrin 2001:100; Conrad 2001). This is most evident in his translation of the Quran (Kánte n.d.; Davydov 2012) which, if taken as legitimate, removes the need for an Arabic-proficient Quranic teacher to school oneself in Islam. In this respect, N'ko and the madrasa movement therefore were sister reform projects of democratizing access to much of the Islamic knowledge of the traditional Quranic schooling system.

To Kantè's mind, his attempts to develop an appropriate way of writing his mother-tongue would help spread Islam and its proper practice. As such, he did not shy away from presenting it to the Quranic elite. Unfortunately, their reaction was the same as when they had reviewed his Ajami orthographies. Kantè (2004:5-6), in response, invoked the life and acts of the Prophet Muhammad:

ه్ב

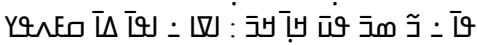

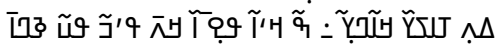
Џ

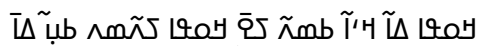
ชิ

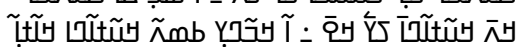

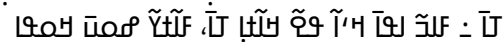

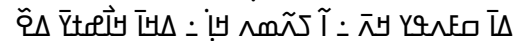

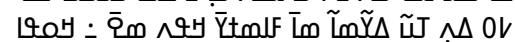

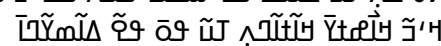

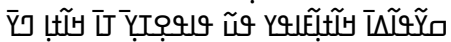

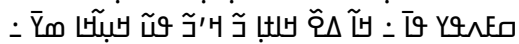
$\bar{U}$ نَ آ

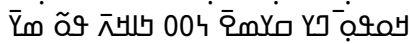

Once the N'ko alphabet was shown to clerical people, they also said "What?! An alphabet that God didn't send down." In their mind, God sent the Arabic alphabet down to the Prophet, when in fact the Prophet himself didn't know any writing system before the revelation of the Quran. The Prophet didn't learn any script, but he recited the Quran because God had him do so. Of the 10 pagans caught during the Battle of Badir, the Prophet took the learned ones, made them teach reading and writing to the illiterate Muslims of Madina and [thereby] made instruction their kùnká [tribute/price of freedom]. Those that didn't teach people each had to pay a tribute in gold of 1 kilo and 600 grams. 
For Kantè, this act of Muhammad was important evidence of the Islamic responsibility to spread literacy. To his mind, however, literacy should not be sought out in just any language. Working toward an Islamic conclusion about translation and mother-tongue education, Kantè (2004:6) called upon the holy book itself:

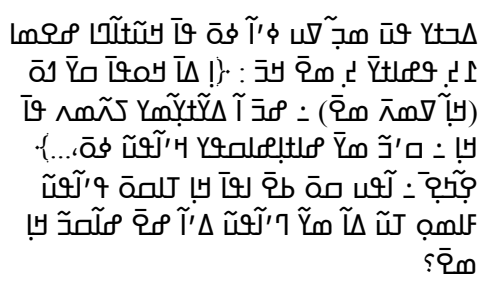

Scholars even see it in Sura 14, Line 4: "We haven't sent a Prophet in any other language but the language of his people so that he can explain things to them." Aha! How can they deliver the word of God to their kin if they do not say it in the fatherland's language?

Of course, Islam for centuries has been relayed to West Africans through the Quranic schooling tradition as outlined above. To Kantè's mind though, oral explanation to the masses was simply not sufficient. It would not necessarily generate that which was central to embracing Islam—understanding (Kánte 2004:6):

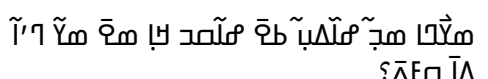
How will religion be understood in the fatherland's language if it isn't written?

Kantè held that being a good Muslim requires understandingsomething that he believed is most easily achieved through mother-tongue education-but true understanding requires text-mediated learning. Indeed, writing occupies much the same role in Kantè's theory of communication which he lays out in N'ko Kángbe' Kùnbába' (Big Book of N'ko Grammar, Kánte 2008c:3-4):

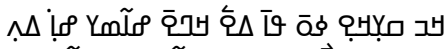
כَّ 定

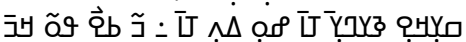

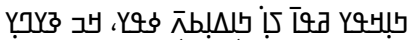

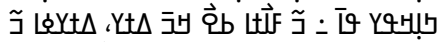

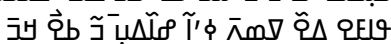

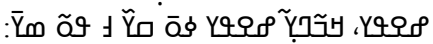
تو $[\ldots]$
The part of the body in which a thing's sign [sinkon] is seen is called the mind. The mind's container is the brain. The thing in which the mind looks for signs is thought, consciousness or one's spirit. The process of identifying things' signs in thought, that process is called reasoning. Expressing reasoning so that someone else can understand it, that is communication [ $f j l i]$. Yet, there are three kinds of communication: gesture, speech, and writing. $[\ldots]$ 
مترح

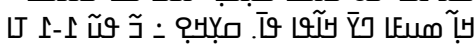
جَ تأ نإ

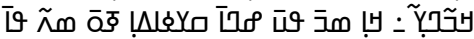

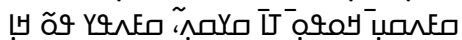

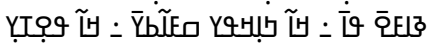

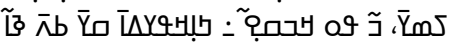

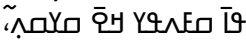

Writing is putting the signs of speech on paper with pen and ink. The individual signs' names are letters. An alphabet is all of one language's letters put together. Almost every language has a particular alphabet. But, nowadays many languages are grouped together under one alphabet. Writing clarifies language, supports thought, and promotes knowledge. For this reason, no intelligent person thrives without writing nowadays.

Combining this pedagogical perspective regarding mother-tongue education, his theory of the written word's power and his conceptualization of the role of understanding in spreading Islam, Kantè (2004:6) came to the following conclusion

\section{دَ б̆ Ù | l

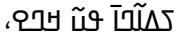

All of this thus shows that ever since the time of Islam's arrival in our lands, Islamic scholars [móri] should have written our languages and explained [the] religion in them.

N'ko's founder did not call for an end to Arabic literacy and proficiency (or that of French for that matter); for him, Arabic was undoubtedly the preferred language of Islam (Kánte 2008b:4). Nonetheless, given that few African Muslims understand it, Kantè (2004:6) questioned how realistic it was to focus on Arabic acquisition instead of mother-tongue education:

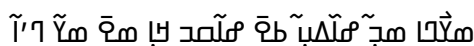 Ū'Q⿻ ؟ธ̄ٓ}

"How will the religion be understood in a mother-tongue [fàsó'kán'] if it isn't written? Or will everyone [need to] become Arabic proficient in order to [kànató understand the religion?"

This commentary about Arabic proficiency presupposes the voices of his interlocutors of the day: Madrasa reformers who were actively working to promote Arabic-language instruction as the best way forward for West African Muslims. By the 1950s, Manding Muslim society was polarized, and people had to take a stance vis-à-vis the reform movement (Kaba 1974:50). Kantè, like his fellow Muslims and Quranic teachers, hoped to strengthen and spread Islam; N'ko would contribute to that (Kánte 2004:1). That said, he explicitly distanced himself from certain voices within West African Islam: 
$\tilde{~ ב . ~}$ $\Lambda$ :

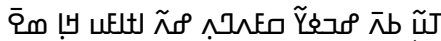

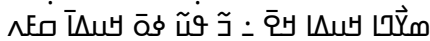
Үm
Where we are from, most people who master the Arabic language are religious fanatics [dína-fato lù, lit. "crazy religious people"], they only want to write in Arabic about religious affairs, and anything that is written on other things is considered by them as paganism. (Kánte 2008b:4)

Such remarks, placed alongside his own extensive writings on Manding history, customs, and Islam suggest Kantè's N'ko was a direct intervention in the emergent "Islamic sphere" of West Africa and not simply a reaction to Marwa's racism or colonial injustice. Kantè's N'ko writings suggest goals similar to those undergirding the madrasa movement: unmediated access to God (Kánte 2007/1958:1) and Islam without the distortions introduced by man (Kánte 2008b:4). Nonetheless, as the above and his many nonIslamic writings make clear, he also acted in response to the numerous reformist or "Wahhabi" voices that he undoubtedly encountered and likely viewed as committed to the further Arabization of West Africa (see allusions to this in Oyler 2005:40,73).

Clearly, Kantè's intervention cannot be limited to the Islamic sphere. N'ko and the madrasa movement both used this medium of instruction as a means to simultaneously reform Quranic schooling and undermine French colonialism. If, among other things, the madrasa movement sought to use Arabic to re-insert West Africa into a global Islamic community, what did Kantè seek in promoting mother-tongue education for Manding speakers?

While clearly Islamic on one hand, his focus on mother-tongue orthography and standardization along with his writings on Manding history and culture link his concerns to other ethno-nationalist rumblings of the late colonial era on the other. In Guinea of the 1940s, prior to the rise of the pan-French West Africa party, the Rassemblement Démocratique Africain, "[t]he political arena was dominated by regional and ethnic associations promoting the interests of their particular constituencies: Peul, Malinke [viz. Manding], Susu, and the people of the forest region" (Schmidt 2005:33). N'ko can be understood as an intellectual counterpart to the relevant ethnic association of Kantè's home region of Upper Guinea, the Union du Mandé (d'Avignon 2012:10). This is not to say that Kantè was commissioned by or working directly for that group; this sort of connection would have been difficult given that Kantè spent most of the 1940s in Côte d'Ivoire. Even following independence, Kantè never seems to have been directly involved with politics, whether in Guinea, Mali (1977-1982), or Côte d'Ivoire (19821984). Regardless of this lack of connections with political parties pre- or post-independence, his writings on Manding language, history, and traditions were certainly works that could "foster coherence and self-consciousness" (Cooper 2002:59) among Manding people as Dianne Oyler (2005) and Christopher Wyrod (2003) argue. 
In sum, Kantè's N'ko was an intellectual project that straddled two seemingly disparate worlds: that of Islam, and that of worldly political concerns pursued through ethno-nationalism or pan-Africanism. Kantè was not simply a cultural nationalist who happened to be a Quranic teacher, though. His actions and accomplishments were unique, but his goal of valorizing African and specifically Manding ways of being while also affirming equal status within the global Muslim community was not. This approach was long present in West African intellectual circles, as evident in the Ajami tradition reviewed in the previous section.

\section{Conclusion}

Kantè's legacy lives on today through the grassroots publishing, broadcasting, and education efforts of thousands of his West African students. Together, they undoubtedly produce more printed text in a year than in all of the official State-backed Latin-based orthographies for Manding combined. From where does such support stem? We can usefully begin to respond to this question through the life and work of N'ko's intellectual founding father as analyzed above.

First, the inventor of the N'ko script was firmly rooted within the "discursive tradition" of Islam (Asad 1986). His writing system was unique, but his concern with using a local African language to better spread the religion was not. Following in the footsteps of Fulani, Hausa, Wolof, and Manding West African Muslims that arose starting at least two centuries before him, he believed that African languages had an integral role to play in disseminating Islam. While these languages and Manding had long been used orally to this end, Kantè, like Samba Mambeyaa, Usman Dan Fodio, Muusaa Ka, and Alfa Mahmud Kàbá saw the benefit of reading and writing in them. Indeed, for Kantè, literacy was not just essential to learning and logical thought but also an Islamic responsibility that could be traced back to God's Messenger, Muhammad. Despite this sentiment and his Islamic scholarship, Kantè never claimed the mantle of a religious leader. From Kantè's perspective as the inventor of N'ko, his contribution in the Islamic domain was primarily a pedagogical one.

Second, Kantè's intervention spoke to his historical moment and the future he envisioned for society. Traveling and living directly amidst the reformist circles that were gaining steam in the Manding-speaking areas of Mali, Guinea, and Côte d'Ivoire, Kantè's orthographic experimentations that culminated in the invention of N'ko in 1949 were his mother-tongue response to the madrasa movement's championing of Arabic-medium education. In this sense, Kantè's actions and his subsequent thirty-eight years of writing, research, and teaching were not only responses to Kamal Marwa and French colonialism, but to his Islamic sphere contemporaries. N'ko as his oeuvre, then, is also an important example of an Islamically-educated African doing the same intellectual work around ethnic solidarity that is often seen as emanating from "the first or second generation of 
western-educated people" (Cooper 2002:59), the implication being that such sympathies were in large part fanned by the Western institutions behind them: churches, colonial officers, and schools.

Kantè-and therefore the N'ko movement of today-must be understood as Islamic in addition to any readings of it as anti-colonial, panAfricanist, or ethno-nationalist.

\section{Acknowledgments}

The writing and editing phase for this article were supported by a grant from the German Research Foundation (DFG) for the project "African voices in the Islamic manuscripts from Mali: documenting and exploring African languages written in Arabic script (Ajami)" (Project Number 344888349). In this regard, I thank my colleagues Dmitry Bondarev and Djibril Dramé.

\section{ו} Hב

\section{References}

Abitbol, M. 1992. "The End of the Songhay Empire." In UNESCO General History of Africa, V: Africa from the Sixteenth to the Eighteenth Century, edited by B. A. Ogot, V:300-26. Berkeley: University of California Press.

African Ajami Library. n.d. "Mandinka Ajami and Arabic Manuscripts of Casamance Senegal.” Boston University. http://hdl.handle.net/2144/27112.

Africa's Sources of Knowledge-Digital Library Project. n.d. "Mandinka Documents." Harvard University. http:/ /ask-dl.fas.harvard.edu/collection/Mandinka.

_. n.d. "Pulaar Documents." Harvard University. http://ask-dl.fas.harvard. edu/collection/pulaar.

Amselle, Jean-Loup. 2001. Branchements: Anthropologie de l'universalité Des Cultures. Paris: Flammarion.

— 2003. "Peut-on être musulman sans être arabe? : A propos du N'ko malinké d'Afrique de l'Ouest." In Islam et villes en Afrique au sud du Sahara: entre soufisme et fondamentalisme, edited by Adriana Piga and Costanza Ventura. Paris: Karthala.

Asad, Talal. 1986. "The Idea of an Anthropology of Islam." In Center for Contemporary Arab Studies. Occasional Paper Series. Washington, DC: Georgetown University.

Austen, Ralph A. 2010. Trans-Saharan Africa in World History. New York: Oxford University Press.

Babou, Cheikh Anta. 2007. Fighting the Greater Jihad: Amadu Bamba and the Founding of the Muridiyya of Senegal, 1853-1913. Athens, Ohio: Ohio University Press.

Baldi, Sergio. 2008. Dictionnaire Des Emprunts Arabes Dans Les Langues de l'Afrique de l'Ouest et En Swahili. Paris: Editions Karthala.

Blommaert, Jan. 2008. Grassroots Literacy: Writing, Identity and Voice in Central Africa. London: Routledge.

Brenner, Louis. 1991. "Médersas au Mali: Transformation d'une institution islamique." In L'enseignement islamique au Mali, edited by Louis Brenner and Binta Sanankoua, 63-85. Bamako, Mali: Editions Jamana. 
2001. Controlling Knowledge: Religion, Power, and Schooling in a West African Muslim Society. Bloomington, IN: Indiana University Press.

—. 2008. "Education, School." Edited by John Middleton and Joseph C. Miller. New Encyclopedia of Africa. Gale Virtual Reference Library. Detroit: Charles Scribner's Sons.

Brenner, Louis, and Murray Last. 1985. "The Role of Language in West African Islam.” Africa: Journal of the International African Institute 55 (4): 432-46.

Bondarev, Dmitry. 2013. "Qur'anic Exegesis in Old Kanembu: Linguistic Precision for Better Interpretation.” Journal of Qur'anic Studies 15 (3): 56-83.

Camara, Sana. 1997. “'A'jami’ Literature in Senegal: The Example of Sëriñ Muusaa Ka, Poet and Biographer.” Research in African Literatures 28 (3): 163-82.

Condé, Ibrahima. 2008a. "Soulemana Kanté Entre Linguistique et Grammaire : Cas de La Langue Littéraire Utilisée Dans Les Textes En N'ko.” St. Petersburg, Russia, conference paper from Deuxième congrès de la linguistique et des langues mandés.

- 2008b. "The Emergence of N'kophone Literature: From Poetry to the Novel." Mande Studies 10: 133-48.

Condé, Nafadji Sory. 2017. Introduction Au N'ko: Une Alternative Linguistique Pour l'Afrique. Paris: l'Harmattan.

Conrad, David. 2001. "Reconstructing Oral Tradition: Souleymane Kanté's Approach to Writing Mande History." Mande Studies 3: 147-200.

Cooper, Frederick. 2002. Africa since 1940: The Past of the Present. Cambridge: Cambridge University Press.

Cooper, Robert L. 1989. Language Planning and Social Change. Cambridge: Cambridge University Press.

Dalby, David. 1971. "Introduction: Distribution and Nomenclature of the Manding People and Their Language." In Papers on the Manding, edited by Carleton Hodge, 3:1-13. African Series. Bloomington: Indiana University Publications.

d'Avignon, Robyn. 2012. "Ethnopolitics in Glass Jars: N'ko Literacy and the Making of a Mande Scientific Territory in Twentieth Century Guinea." In 2012 Africa History and Anthropology Workshop. Ann Arbor, MI.

Davydov, Artem. 2012. "On Souleymane Kanté's Translation of the Quran into the Maninka Language.” Mandenkan 48: 3-20.

Delafosse, Maurice. 1904. Vocabulaires comparatifs de plus de 60 langues ou dialectes parlés à la Côte d'Ivoire et dans les régions limitrophes : avec une bibliographie et une carte. Paris : E. Leroux.

Derive, Marie-Jo, ed. 1978. Table ronde sur les origines de Kong: les 1-2-3 novembre 1975 à Kong. Annales de l'Université d'Abidjan. Abidjan, Côte-d'Ivoire: Université nationale de Côte-d'Ivoire, Institut d'histoire d'art et d'archéologie africains [et] Institut de linguistique appliquée.

Diallo, Ibrahima. 2012. "Qur'anic and Ajami Literacies in Pre-Colonial West Africa." Current Issues in Language Planning 13 (2): 91-104.

Donaldson, Coleman. 2013. "Jula Ajami in Burkina Faso : A Grassroots Literacy in the Former Kong Empire." Working Papers in Educational Linguistics 28 (2): $19-36$.

_. 2017. "Clear Language: Script, Register and the N'ko Movement of MandingSpeaking West Africa.” Doctoral Dissertation, University of Pennsylvania.

Dumestre, Gérard, and Valentin Vydrin. 2014. "Manding Ajami Samples: Mandinka and Bamana." In The Arabic Script in Africa: Studies in the Use of a Writing System, 
edited by Meikal Mumin and Kees Versteegh, 225-60. Studies in Semitic Languages and Linguistics 71. Leiden: Brill.

Fofana, Khalil I. 1998. L’Almami Samori Touré Empereur : Récit Historique. Paris: Présence Africaine.

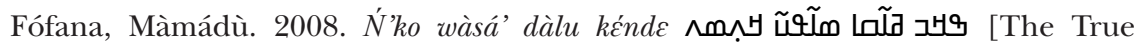
Vindication of N'ko]. Bamako, Mali: Bakoroba.

Green, Christopher R., and Jennifer Hill Boutz. 2016. "A Prosodic Perspective on the Assignment of Tonal Melodies to Arabic Loanwords in Bambara." Mandenkan 56: 29-76.

Hornberger, Nancy H., and David Cassels Johnson. 2007. "Slicing the Onion Ethnographically: Layers and Spaces in Multilingual Language Education Policy and Practice." TESOL Quarterly 41 (3): 509-32.

Hunwick, John O. 1964. "The Influence of Arabic in West Africa: A Preliminary Historical Survey." Transactions of the Historical Society of Ghana 7: 24-41.

—. 2004. "West Africa and the Arabic Language." Sudanic Africa 15: 133-44.

Juffermans, Kasper, Yonas Mesfun Asfaha, and Ashraf Abdelhay. 2014. "African Literacy Ideologies, Scripts and Education.” In African Literacies: Ideologies, Scripts, Education, 1-62. Cambridge: Cambridge Scholars Publishing.

Kaba, I. (2011a). الشعر العربي في الغرب الإفريقي [Arabic poetry of West Africa] (Vol. Supplements). Islamic Educational, Scientific and Cultural Organization (ISESCO).

C. (2011b). الثعر العربي في الغرب الإفريقي [Arabic poetry of West Africa] (Vol. III). Islamic Educational, Scientific and Cultural Organization (ISESCO).

-. (2011c). الثعر العربي في الغرب الإفريقي [Arabic poetry of West Africa] (Vol. I). Islamic Educational, Scientific and Cultural Organization (ISESCO).

Kaba, Lansiné. 1974. The Wahhabiyya: Islamic Reform and Politics in French West Africa. Evanston: Northwestern University Press.

- 2004. Cheikh Mouhammad Chérif et son temps: ou Islam et sociéte à Kankan, Guinée (1874-1955). Paris: Présence africaine.

Kane, Ousmane Oumar. 2016. Beyond Timbuktu. Cambridge: Harvard University Press.

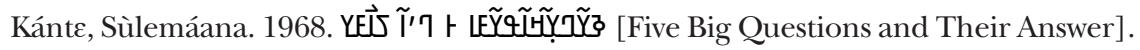
Edited by Bàbá Màmádi Jàane.

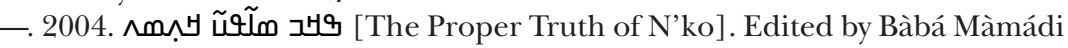
Jàane. Bamako: Bakoroba.

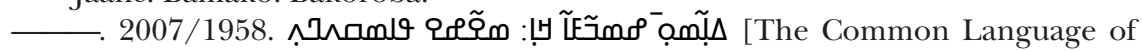
Manden: An Abridged History]. Edited by Màmàdú Jàrà. Bamako: Bakoroba.

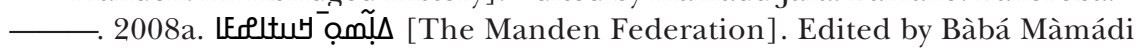
Jàanc. Cairo.

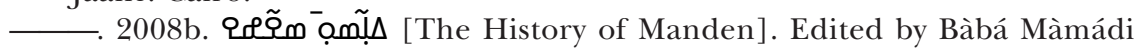
Jàane. Cairo.

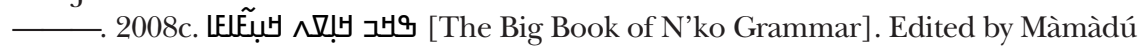
Jàrà. Bamako: Bakoroba.

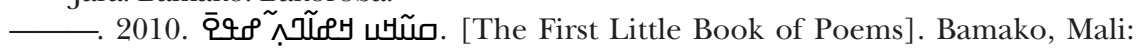
Bakoroba.

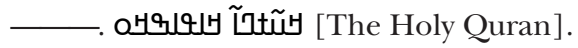

Kodjo, Georges Niamkey. 2006. Le royaume de Kong, Côte d'Ivoire: des origines à la fin du XIXème siècle. Paris: l'Harmattan.

Last, Murray. 1967. The Sokoto Caliphate. Ibadan History Series. New York: Humanities Press. 
Launay, Robert. 1983. Traders Without Trade Trade: Responses to Change in Two Dyula Communities. Cambridge: Cambridge University Press.

Launay, Robert, and Benjamin F. Soares. 1999. "The Formation of an "Islamic Sphere' in French Colonial West Africa." Economy and Society 28 (4): 497-519.

LeBlanc, Marie Nathalie. 1999. "The Production of Islamic Identities through Knowledge Claims in Bouaké, Côte d'Ivoire.” African Affairs 98 (393): 485-508.

Levtzion, Nehemia. 1973. Ancient Ghana and Mali. London: Methuen.

_ 1975. "North-West Africa: From the Maghrib to the Fringes of the Forest." In The Cambridge History of Africa, IV:142-222. C. 1600-c. 1790. Cambridge: Cambridge University Press.

Mack, Beverly B., and Jean Boyd, ed. 2000. One Woman's Jihad: Nana Asma'u, Scholar and Scribe. 4.1.2000 edition. Bloomington: Indiana University Press.

Massing, Andreas W. 2000. "The Wangara, an Old Soninke Diaspora in West Africa? (Les Wangara, Une Vieille Diaspora Soninke d'Afrique de l'Ouest?)." Cahiers d'Études Africaines 40 (158): 281-308.

McLaughlin, Fiona. 2017. "Ajami Writing Practices in Atlantic-Speaking Africa." In The Atlantic Languages, edited by Friederike Lupke. Oxford: Oxford University Press.

Mommersteeg, Geert. 2012. In the City of the Marabouts: Islamic Culture in West Africa. Translated by Diane Webb. Long Grove, Illinois: Waveland Press.

Monteil, Vincent. 1980. L'Islam Noir: Une religion à la Conquête de l'Afrique. III édition refondue. Paris: Seuil.

Mugane, John. 2017. "The Odyssey of 'Ajamī and the Swahili People." Islamic Africa 8 (1-2): 193-216.

Mumin, Meikal. 2014. "The Arabic Script in Africa. Understudied Literacy." In The Arabic Script in Africa. Studies in the Use of a Writing System, edited by Meikal Mumin and Kees Versteegh, 41-78. Leiden: Brill.

Mumin, Meikal, and Kees Versteegh, ed. 2014. The Arabic Script in Africa: Studies in the Use of a Writing System. Studies in Semitic Languages and Linguistics 71. Leiden: Brill.

Ngom, Fallou. 2009. "Aḥmadu Bamba's Pedagogy and the Development of 'Ajamī Literature." African Studies Review 52 (01): 99-123.

—. 2010. "Ajami Scripts in the Senegalese Speech Community." Journal of Arabic and Islamic Studies 10: 1-23.

- 2016. Muslims beyond the Arab World: The Odyssey of Ajami and the Muridiyya. Oxford, England: Oxford University Press.

- 2017. "West African Manuscripts in Arabic and African Languages and Digital Preservation." In Oxford Research Encyclopedia of African History.

Osborn, Emily Lynn. 2011. Our New Husbands Are Here: Households, Gender, and Politics in a West African State from the Slave Trade to Colonial Rule. Athens, Ohio: Ohio University Press.

Oyler, Dianne White. 2005. The History of the N'ko Alphabet and Its Role in Mandé Transnational Identity: Words as Weapons. Cherry Hill, New Jersey: Africana Homestead Legacy Publishers.

Person, Yves. 1968. Samori : Une Révolution Dyula. Mémoires de l'Institut Fondamental d'Afrique Noire 80. Dakar, Senegal: Institut fondamental de l'Afrique noire.

Peterson, Brian J. 2008. "History, Memory and the Legacy of Samori in Southern Mali, C. 1880-1898." The Journal of African History 49 (2): 261-79.

Peterson, Derek. 2006. "Language Work and Colonial Politics in Eastern Africa: The Making of Standard Swahili and 'School Kikuyu." In The Study of Language and the Politics of Community in Global Context, edited by David L. Hoyt and Karen Oslund, 185-214. Plymouth, United Kingdom: Lexington Books. 
Ranger, Terence. 2010. "The Invention of Tradition in Colonial Africa." In Perspectives on Africa: A Reader in Culture, History and Representation, edited by Roy Richard Grinker, Stephen C. Lubkemann, and Christopher B. Steiner. Malden, Mass.: John Wiley \& Sons.

Robinson, David. 1982. "Fulfulde Literature in Arabic Script." History in Africa 9: 251-61.

Salvaing, Bernard. 2004. "Colonial Rule And Fulfulde Literature In Futa Jallon (Guinea)." Sudanic Africa 15: 111-32.

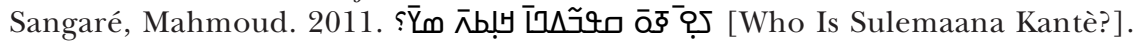
Bamako, Mali.

Schmidt, Elizabeth. 2005. Mobilizing the Masses : Gender, Ethnicity, and Class in the Nationalist Movement in Guinea, 1939-1958. Portsmouth, New Hampshire: Heinemann.

Sanneh, Lamin O. 1989. The Jakhanke Muslim Clerics: A Religious and Historical Study of Islam in Senegambia. Lanham, Maryland: University Press of America.

- 2016. Beyond Jihad: The Pacifist Tradition in West African Islam. Oxford: Oxford University Press.

Simonis, Francis. 2010. L'Afrique soudanaise au Moyen âge: le temps des grands empires (Ghana, Mali, Songhaï). Marseille: Scérén-CRDP de l'académie d'Aix-Marseille.

Tamari, Tal. 1994. "Cinq textes bambara en caractères arabes: présentation, traduction, analyse du système graphique.” Islam et Sociétés au Sud du Sahara (8): 97-121.

— 2006. "L'Enseignement Islamique de Niveau Avancé: Cursus, Pédagogie, Implications Culturelles et Perspectives Comparatives." Mande Studies 8: $39-62$.

- 2016. "Styles of Islamic Education: Perspectives from Mali, Guinea, and The Gambia." In Islamic Education in Africa: Writing Boards and Blackboards, edited by Robert Launay, 29-60. Bloomington: Indiana University Press.

- 2017. "Bamana Texts in Arabic Characters: Some Leaves from Mali." In

The Arts and Crafts of Literacy: Islamic Manuscript Cultures in Sub-Saharan Africa, edited by Andrea Brigaglia and Mauro Nobili. Berlin: Walter de Gruyter GmbH \& Co KG.

Tamari, Tal, and Dmitry Bondarev. 2013. "Introduction and Annotated Bibliography." Journal of Qur'anic Studies 15 (3): 1-55.

Turcotte, Denis. 1983. Lois, règlements et textes administratifs sur l'usage des langues en Afrique occidentale français (1826-1959): répertoire chronologique annoté. Québec: Les Presses de l'Université Laval.

Vydrin, Valentin. 1998. "Sur l'écriture Mandingue et Mandé En Caractères Arabes (Mandinka, Bambara, Soussou, Mogofin).” Mandenkan (33): 1-86.

- 2001. "Souleymane Kanté, Un Philosophe-Innovateur Traditionnaliste Maninka vu à Travers Ses Écrits En Nko.” Mande Studies, no. 3: 99-131.

—. 2012. "Une Bibliographie Préliminaire Des Publications Maninka En Écriture N'ko.” Mandenkan (48): 59-120.

- 2014. "Ajami Scripts for Mande Languages." In The Arabic Script in Africa: Studies in the Use of a Writing System, edited by Meikal Mumin and Kees Versteegh, 199-224. Studies in Semitic Languages and Linguistics 71. Leiden: Brill.

Ware III, Rudolph T. 2014. The Walking Qur'an: Islamic Education, Embodied Knowledge, and History in West Africa. Chapel Hill: The University of North Carolina Press.

Wilks, Ivor. 1968. "The Transmission of Islamic Learning in the Western Sudan.” In Literacy in Traditional Societies, edited by Jack Goody, 162-97. Cambridge: Cambridge University Press. 
- 2000. "The Juula and the Expansion of Islam into the Forest." In The History

of Islam in Africa, edited by Nehema Levtzion and Randell Pouwels, 93-115. Athens, Ohio: Ohio University Press.

Wyrod, Christopher. 2003. "The Light on the Horizon: N'ko Literacy and Formal Schooling in Guinea.” Master's Thesis, George Washington University.

. 2008. "A Social Orthography of Identity: The N'ko Literacy Movement in West Africa." International Journal of the Sociology of Language 192 (January).

Zappa, Francesco. 2011. "When Arabic Resonates in the Words of an African Language: Some Morphological Features and Semantic Features of Arabic Loanwords and Calques in Bambara." In The Word in Arabic, edited by Giuliano Lancioni and Lidia Bettini, 229-49. Leiden: Brill.

Zito, Alex. 2012. "Prosperity and Purpose, Today and Tomorrow: Shaykh Ahmadu Bamba and Discourses of Work and Salvation in The Murridiya Sufi Order of Senegal.” Doctoral Dissertation, Boston University.

\section{Notes}

1. Henceforth <Sulemaana Kantè>, ignoring tonal diacritics and using <è $>$ in place of $\langle\varepsilon>$, except in citations (e.g., Kánt $\varepsilon$ 2008a) where I note his name using the Latin-based Manding transliteration system. I have opted to write Kantè's first name as Sulemaana given that it is written as such by Kantè himself in the majority of his works that I have in my personal archive (see Vydrin 2012:63 for a discussion).

2. The term kàramós has a range of one-to-one equivalents: Wolof sëriñ, Fulani ceerno, Soninke móodì (< Ar. mu'addib 'educator,' Baldi 2008:42). Today many translate it with the French colonial term marabout (<Ar. murābit 'holy ascetic').

Here, I use the common Latin-based spelling kàramśs instead of a strict transliteration of the N'ko spelling. When writing Manding in Latin script, I use phonemic orthography synthesizing the various national standards while also marking tone. Grave diacritics mark low tones and acute diacritics mark high tones. An unmarked vowel carries the same tone as the last marked vowel before it. The tonal article on nouns is noted by an apostrophe but not in citation.

3. See Kaba (2004) and Osborn (2011).

4. See Sangaré 2011:6.

5. See Tamari's (2016) most recent of her many investigations of Quranic education among Manding and other West African language speakers.

6. See Mommersteeg 2012; Tamari 2006:40; Tamari and Bondarev 2013:7-8.

7. Though note the important role of the Pashalik of Timbuktu (Abitbol 1992; Levtzion 1975).

8. See Hunwick 1964:30.

9. See Kánte 1968.

10. See Condé 2008a.

11. See Oyler 2005; Wyrod 2003; Wyrod 2008.

12. On Islam Noir, see Monteil 1980.

13. This holds true for N'ko publications more generally (Vydrin 2012).

14. For references to languages outside of those covered here, see McLaughlin 2017; Mumin and Versteegh 2014; Mugane 2017.

15. Mumin 2014; Mumin and Versteegh 2014.

16. Cooper 1989. 
17. Despite recent scholarship (Kane 2016; Sanneh 2016; Kaba 2011a-c), an overarching account for the historical emergence of African language literacy in Arabic script remains to be done.

18. See Last 1967.

19. See Brenner and Last 1985:424.

20. For modern Fuuta Toro Ajami manuscripts, see "Pulaar Documents" from the Africa's Sources of Knowledge - Digital Library Project.

21. شريف sharif 'noble, highborn'; typically used to refer to descendants of the Prophet Muhammad.

22. See Levtzion 1973; Simonis 2010.

23. Tamari and Bondarev 2013:15.

24. Though see documentations of twentieth century Bamanan Ajami (e.g., Dumestre \& Vydrin 2014; Tamari 1994, 2017); See Sanneh 1989.

25. See Tamari 2017; Vydrin 2014. Digital collections of Mandinka Ajami Manuscripts are hosted in Boston University's African Ajami Library ("Mandinka Ajami and Arabic Manuscripts of Casamance Senegal”) and Harvard's Africa's Sources of Knowledge - Digital Library ("Mandinka Documents")

26. See Delafosse 1904; Marty 1922 cited in Hunwick 2004.

27. See Derive 1978; Kodjo 2006.

28. Commonly spelled Samory or Samori Touré.

29. Alfa Mahmud is said to have introduced the Tijaniyya brotherhood to Kankan after studying and living in the entourage of al-Hajj Umar Tal (Osborn 2011:74-82).

30. The first poem in Kantè's (2010) first book of poems is entitled If జ̃ ำ Nósro' lù bá'. ('The sea of lights') and is a translation of one of Alfa Mahmud Kàbá's Arabic language poems (Baḥr al-anwār بحر الانوار).

31. A picture of him is included in Kaba 2011a:986.

32. In 2016 in Kankan I was shown a photocopy of a Manding Ajami manuscript produced prior to the introduction of Kantè's N'ko.

33. This perspective of Kantè, on a lack of an African written tradition, is, of course inaccurate in a strict sense; see Ngom 2017.

34. Sometimes written as médersa in French.

35. For the purposes of this article I will not address this part of Kantè's thought. See Donaldson 2017.

36. A large number of African orthographies flourished at this time (Juffermans, Asfaha, \& Abdelhay 2014). 